\title{
The Multiple Roles of B Cells in Multiple Sclerosis and Their Implications in Multiple Sclerosis Therapies
}

\author{
Rui Li and Amit Bar-Or \\ Perelman School of Medicine, University of Pennsylvania, Philadelphia, Pennsylvania 19104 \\ Correspondence: amitbar@upenn.edu
}

Increasing evidence has suggested that both antibody-dependent and antibody-independent functions of B cells are involved in multiple sclerosis (MS). The contrasting results of distinct Bcell targeting therapies in MS patients underscores the importance of elucidating these multiple B-cell functions. In this review, we discuss the generation of autoreactive B cells, migration of B cells into the central nervous system (CNS), and how different functions of B cells may contribute to MS disease activity and potentially mitigation in both the periphery and CNS compartments. In addition, we propose several future therapeutic strategies that may better target/shape B-cell responses for long-term treatment of MS.

\begin{abstract}
$A^{\text {lthough } \mathrm{T} \text { cells have historically been con- }}$ Asidered the key players in multiple sclerosis (MS) pathogenesis, selective depletion of B cells with anti-CD20 antibodies has proven highly effective in limiting new MS disease activity (Bar-Or et al. 2008, 2014; Hauser et al. 2008, 2017; Kappos et al. 2011; Sorensen et al. 2014). The two independent phase III (OPERA I and OPERA II) clinical trials of the humanized antiCD20 monoclonal antibody orelizumab showed a $>94 \%$ decrease in new magnetic resonance imaging (MRI) lesion development with robust effects on MS relapses, as compared with the interferon (IFN)- $\beta$ treated group (Hauser et al. 2017). Although essentially all approved immune therapies for relapsing remitting MS (including IFN- $\beta$, copaxone, tysabri, gilenya, tecfidera, and alemtuzumab) were developed largely with a view of how they may impact $\mathrm{T}$ cells in
\end{abstract}

MS, all of these therapies are now also known to directly impact B-cell responses (Cupps et al. 1985; Genc et al. 1997; Duda et al. 2000; Salama et al. 2003; Duddy et al. 2007; Begum-Haque et al. 2010; Kala et al. 2010; Ramgolam et al. 2011; Miyazaki et al. 2014b; Nakamura et al. 2014; Li et al. 2017).

Of note, not all treatments targeting B cells have been beneficial for MS patients. In fact, atacicept (a fusion protein of TACI and Fc fragment of immunoglobulin (Ig)G that targets B cells and plasma cells but relatively spears memory B cells) appeared to worsen. In fact, atacicept (a fusion protein of TACI and $\mathrm{Fc}$ fragment of IgG that targets B cells and plasma cells but relatively spears memory B cells) appeared to worsen central nervous system (CNS) inflammatory disease in MS and optic neuritis studies (Kappos et al. 2014; Sergott et al. 2015). In

Editors: Howard L. Weiner and Vijay K. Kuchroo

Additional Perspectives on Multiple Sclerosis available at www.perspectivesinmedicine.org

Copyright (C) 2019 Cold Spring Harbor Laboratory Press; all rights reserved; doi: 10.1101/cshperspect.a029108

Cite this article as Cold Spring Harb Perspect Med 2019;9:a029108 
autoimmune encephalomyelitis (EAE) (a commonly used animal model for neuroinflammation), the outcome of targeting B cells can also be either beneficial or detrimental. The particular effect observed appears to hinge on several factors. Matsushita et al. (2008) showed that depleting $\mathrm{B}$ cells before immunization worsens disease activity while depleting B cells after disease induction improves disease activity, indicating that B cells may play different roles at different disease stages. In addition, the antigens used to induce EAE also seem to play an important role. For example, depleting B cells in an EAE model induced with recombinant myelin oligodendrocyte glycoprotein (MOG) protein results in reduced disease activity, although disease exacerbation was observed when B cells were depleted in an EAE model using the MOG35-55 peptide to induce disease (Weber et al. 2010).

The opposing outcomes of anti-CD20 and atacicept treatments in MS, together with the observations in EAE, highlights the need for more complete elucidation of the functional heterogeneity that exists among B cells and, in particular, their capacity to either promote or acquiesce CNS inflammation. In recent years, considerable work has expanded our understanding of the diverse functions of B cells in both health and disease. In addition to their potential to differentiate into antibody-producing plasmablasts/plasma cells, B cells can also efficiently present antigen to $\mathrm{T}$ cells, help $\mathrm{T}$ cell activation and differentiation, contribute to the organization of normal and possibly also ectopic lymphoid structures, and modulate local immune responses through secretion of soluble products such as proinflammatory or anti-inflammatory cytokines. Abnormalities in several of these novel B-cell functions have been implicated in MS.

\section{B-CELL TOLERANCE IN MS}

Immune tolerance is generally maintained even though self-reactive (autoreactive) B cells are present in the normal immune repertoire of healthy individuals (McHeyzer-Williams and Nossal 1988; Wardemann et al. 2003; Shlomchik
2008). The physiologic roles of such autoreactive B cells that exist as part of "normal autoimmunity" remain incompletely understood. Abnormalities in B-cell tolerance have been reported in several autoimmune diseases, including SLE, rheumatoid arthritis (RA), type 1 diabetes (T1D), and MS (Samuels et al. 2005; Yurasov et al. 2005; Henry et al. 2012; Kinnunen et al. 2013a). There are two major checkpoints that normally contribute to the elimination or control of autoreactive B cells: central tolerance and peripheral tolerance (Meffre 2011). Central tolerance of B cells is established in the bone marrow and eliminates $\sim 75 \%$ of self-reactive B cells, while peripheral tolerance takes place in the secondary lymphoid organs where most other selfreactive B cells are controlled (Meffre 2011). Bcell receptor (BCR) and Toll-like receptor (TLR) signaling pathways play important roles during the bone marrow selection of B cells, although CD40 ligand, major histocompatibility complex (MHC) II, and regulatory $\mathrm{T}$ cells (Tregs) are important for the control of autoreactive B cells in the periphery (Meffre 2011). Using careful analysis of self-reactive antibody profiles, Meffre and colleagues implicated deficiencies of both central and peripheral B-cell tolerance in patients with SLE, RA, and T1D. In contrast, MS $\mathrm{B}$ cells appear to only display an abnormality in peripheral tolerance (Kinnunen et al. 2013a,b). This result is consistent with the observations that the function of Tregs is deficient in MS patients (Viglietta et al. 2004; Haas et al. 2005; Schwarz et al. 2013). In this regard, it is plausible that the tolerance abnormality observed in MS $\mathrm{B}$ cells may be the consequence of the dysfunction of Tregs. Relatively little is known about how Tregs regulate B-cell tolerance. A subset of CXCR5-expressing Tregs has been described within the classical germinal center (GC) architecture, referred to as follicular regulatory $\mathrm{T}$ (Tfr) cells (Chung et al. 2011; Linterman et al. 2011; Sage et al. 2014a; Vaeth et al. 2014). Subsequent studies showed that, in mice, Tfr cells control B-cell responses indirectly, through CTLA-4-mediated suppression of follicular helper T (Tfh) cells (Sage et al. 2014b; Wing et al. 2014). In MS, both the frequency and immune suppressive function of Tfr is reportedly 
decreased as compared with healthy controls (Dhaeze et al. 2015). Questions remain as to whether and how we may be able to restore peripheral tolerance of B cells in MS patients. Some patients with MS undergoing selective B-cell depletion may experience durable quiescence of their MS disease activity even as their B cells (largely naïve) reemerge, suggesting that a form of tolerance has been achieved. In contrast, B cells reconstituting following less selective depletion (e.g., immune ablation and hematopoietic stem cell transplantation and, particularly, use of the approved anti-CD52 therapy for MS) may manifest with breach in tolerance and the development of secondary (typically antibody-mediated) autoimmune diseases (Coles et al. 2012).

\section{B-CELL TRAFFICKING IN MS}

$\mathrm{B}$ cells (as well as plasmablasts and plasma cells) appear to be fostered in the inflamed MS CNS, in which they have been observed in several subcompartments, including cerebrospinal fluid (CSF), parenchyma, and meninges (Michel et al. 2015). Unlike T cells, there is a relative gap in our understanding of the molecular mechanisms used by B cells to enter the CNS, both in health and disease. CXCL13, one of the most strongly implicated chemokines in regulating B-cell migration (Bagaeva et al. 2006; Henry and Kendall 2010), is abnormally increased in the CSF of MS patients (Krumbholz et al. 2006; Sellebjerg et al. 2009). In addition, a positive correlation has been reported between the number of CSF $\mathrm{B}$ cells and the level of CXCL13 in the MS CSF (Kowarik et al. 2012).

VLA-4 is an adhesion molecule that is involved in immune cells rolling, activation, and arrest during immune cell trans-endothelial trafficking (Takeshita and Ransohoff 2012). Functional blockade of the adhesion molecule VLA-4 using the monoclonal antibody natalizumab substantially decreases new relapsing MS disease activity (Polman et al. 2006; Ransohoff 2007), an effect largely attributed to limiting Tcell trafficking into the CNS (Hyun et al. 2009). However, B cells-and especially memory B cells-also express high levels of VLA-4 (Alter et al. 2003; Niino et al. 2006; Putzki et al. 2010).
Blocking VLA-4 in vitro decreases human B-cell migration across endothelial cells to a greater extent than the decreases observed for $\mathrm{T}$ cells (Alter et al. 2003). In EAE mice, selective knockout of VLA-4 from B cells, substantially reduced accumulation of both $\mathrm{B}$ cells and $\mathrm{T}$ cells in the $\mathrm{CNS}$, and was associated with less severe disease (Lehmann-Horn et al. 2015).

Although classical work using somatic hypermutation analysis of MS CSF B-cell immunoglobulin genes (summarized in Michel et al. 2015 ) initially pointed to clonal expansion of $B$ cells within the CNS, more recent work using similar techniques has identified shared B-cell clones between the CNS and the periphery, including the CNS draining deep cervical lymph nodes of the same patients (von Budingen et al. 2012; Palanichamy et al. 2014; Stern et al. 2014). The molecular analysis of related clones revealed bidirectional trafficking of these B cells (both into and out of the CNS), and suggested that much of the clonal expansion (and presumably activation) of the B cells may in fact occur in the deep cervical lymph nodes (von Budingen et al. 2012; Palanichamy et al. 2014; Stern et al. 2014). These same studies also identified shared clones present in the different CNS subcompartments, namely, the CSF, parenchyma, and meninges of the same patients. When and how B cells enter the CNS through what are now recognized as distinct interfaces (traditional blood-brain barrier endothelial cells, meningeal, and choroidal interfaces), how they migrate among different CNS subcompartments, and what determines their egress from the CNS (e.g., into the cervical lymph nodes), are topics of active investigation.

\section{ABNORMAL ANTIBODY RESPONSES IN MS}

Abnormal antibody production within the CNS has been a well-recognized feature commonly seen in patients with MS. Elevated levels and synthesis rates of both IgG and IgM can be found in the CSF of patients, which, when run on an electrophoretic gel, frequently display a pattern of oligoclonal bands (OCBs) consistent with a restricted number of clonally expanded antibody-producing plasma cells (Ivers et al. 1961; Kostulas et al. 1987; Villar et al. 2002). 
IgG OCBs can be found in the great majority of MS patients. IgM OCBs are present in $~ 30 \%-$ 40\% (Weber et al. 2011), and their presence has been associated in different studies with more active disease (Tintore et al. 2001; Lourenco et al. 2013) and potentially with therapeutic response to B-cell-directed therapy (Villar et al. 2014). Studies have indicated that the CSF antibodies in patients with MS can correspond to the immunoglobulin gene sequences of $\mathrm{B}$ cells and plasma cells isolated from the CSF as well as within CNS tissues (both in typical white matter lesions and in the meninges) of the same patients, indicating sharing of the same B clones and their antibody products in different subcompartments of the same inflamed MS CNS (Lovato et al. 2011; von Budingen et al. 2012; Palanichamy et al. 2014; Stern et al. 2014). Within MS lesions, antibodies can be seen within phagocytic myeloid cells, which may include myelin fragments (Zhou et al. 2006). Such lesions may have distinct imaging features and may be more amenable to antibody-depleting interventions such as plasmapheresis (Breij et al. 2008; Sadaba et al. 2012).

Despite the strong implication of abnormal antibody responses in MS, direct showing of their pathogenicity has been difficult to establish. For example, in contrast to the ability of activated CNS-specific T cells to transfer EAE to naïve animals, antibodies alone appear unable to induce such CNS inflammation (Genain et al. 1995; Mathey et al. 2007; Derfuss et al. 2009). It has also been difficult to elucidate disease-relevant antigenic targets of B cells, plasmablasts, and plasma cells isolated from the CNS of patients. Similarly, the antigenic specificities of the majority of abnormal CSF antibodies in MS (including the overall IgG or IgM as well as the OCB) have not been elucidated despite considerable efforts (reviewed in Michel et al. 2015). Most recently, thorough examination of MS patient OCB-identified antibodies that largely recognized ubiquitous intracellular self-proteins, suggesting that the OCB antibodies may be generated as response to debris (Brandle et al. 2016; Hohlfeld et al. 2016a,b; Winger and Zamvil 2016).

Considerable efforts have also been invested over the years to detect and establish the signifi- cance of circulating anti-CNS antibodies in both adult and pediatric populations with MS and related disorders (Bar-Or et al. 2016). Challenges have included important subtleties of the methodologies used to detect the antibodies, selection of control populations, the aforementioned potential for autoreactive antibodies to develop as a response to (rather than cause of) injury, as well as the realization that self-directed antibodies (including CNS-reactive antibodies) can be commonly detected as part of the normal circulating humoral repertoire. Such normal antibodies may nonetheless contribute to CNS inflammatory disease-for example, individuals who happen to have antimyelin antibodies in their circulation as part of their normal humoral repertoire, but also develop MS, may have a more aggressive presentation-suggesting that presence of such antibodies (themselves normal) can modulate disease expression if they access the CNS (O'Connor et al. 2010).

Despite ongoing efforts to assess whether particular circulating CNS autoantibodies may serve as clinically useful biomarkers (whether for diagnosis, prediction of disease severity or course, or to distinguish pathophysiologic entities that may warrant different therapeutic approaches), the field of MS has not yet implicated CNS autoreactive antibodies in the same compelling way that anti-AQP4 antibodies are implicated in the neuromyelitis-optica spectrum disorders (NMOSDs) or antineuronal antibodies in the spectrum of antibody-mediated encephalitides. Within the broader spectrum of CNS inflammatory demyelinating syndromes, presence of anti-MOG antibodies has been associated in some studies with less aggressive disease, lesser likelihood of relapse and improved outcomes, and may emerge as a non-MS disease phenotype (Sato et al. 2014; Ketelslegers et al. 2015). Anti-MOG antibodies occur more commonly in the pediatric than adult age group (McLaughlin et al. 2009; Probstel et al. 2011; Mayer and Meinl 2012; Bar-Or et al. 2016), although their significance in children (including putative biomarker value) may not be the same as in adults. In addition to considering traditional myelin antigens (such as MOG) as potential antibody targets, serum antibodies to other 
CNS targets have been studied. Circulating antibodies specific to KIR4.1 (ATP-sensitive inward rectifying potassium channel that is largely expressed by glial cells) were reported in approximately half of both adults with MS (Srivastava et al. 2012) and children with acute CNS demyelination (Kraus et al. 2014), although their presence did not appear to associate with a particular clinical phenotype. Other studies did not reproduce the original results (Brickshawana et al. 2014; Nerrant et al. 2014), highlighting the impact of different methodologies used and the importance of direct assay comparison (Waters et al. 2012).

\section{B-CELL ANTIGEN PRESENTATION AND CNS INFLAMMATION}

For a $\mathrm{T}$ cell to be fully activated, it requires antigen presenting cells (APCs) to process and present its antigenic epitope as well as providing the necessary costimulatory signals. Professional APCs include monocyte-derived dendritic cells (mDCs), plasmacytoid dendritic cells (pDCs), and tissue-resident macrophage. These cells sense the antigen/pathogen often through innate immune receptors (such as TLRs), digest these protein molecules into peptides, and present them to T cells through either MHC or nonMHC molecules (Guermonprez et al. 2002; Brigl and Brenner 2004). B cells can also present antigen to $\mathrm{T}$ cells, a process that usually occurs within the secondary lymphoid tissue (Rodriguez-Pinto 2005; Rodriguez-Pinto and Moreno 2005). Compared with professional APCs (that specialize in linear epitope presentation), B cells (that recognize 3-dimensional "conformational" epitopes) can more efficiently present protein antigens and seem to be the main source of APCs when the antigen level is low (Pierce et al. 1988; Rivera et al. 2001). B cells are also highly effective APCs when they recognize the same antigen as $\mathrm{T}$ cells (cognate interaction) (Pierce et al. 1988; Rodriguez-Pinto 2005). Cognate interactions appear important for both effector T-cell activation and Treg-cell generation (Barnett et al. 2014; Walters et al. 2014). APC function of B cells has been highlighted in many disease contexts, including in- fectious diseases, transplantation, and autoimmune diseases (Milich et al. 1997; Serreze et al. 1998; Molnarfi et al. 2013; Zeng et al. 2014). In EAE, B-cell-specific MHC II knockout mice are resistant to recombinant human MOG-induced disease-an EAE model strongly dependent on the presence of B cells (Weber et al. 2010; Molnarfi et al. 2013). Interestingly, knocking out MHC II on B cells also results in a total abrogation of anti-MOG antibody; however, injecting these mice with anti-MOG antibody only partially recovers the EAE phenotype, indicating an antibody-independent but MHC II-dependent role of B cells in EAE (Molnarfi et al. 2013). In the same study, the investigators also found that crossing MOG BCR-specific mice with MOG TCR-specific mice substantially enhanced the incidence of spontaneous EAE (Molnarfi et al. 2013), suggesting that cognate interactions between $\mathrm{B}$ cells and $\mathrm{T}$ cells may be required for optimal EAE induction.

The second signal required for $\mathrm{T}$-cell activation is the costimulatory signal. So far, $>20$ costimulatory molecule pairs have been verified. Of those, CD80/86 and their T-cell-activating binding partner CD28 are the best characterized. $\mathrm{Hu}$ man memory B cells express CD80 and a much smaller subset of B cells express CD86 in the resting state (Bar-Or et al. 2001). Both molecules can be further induced by various B-cell-activating stimuli (both innate and adaptive) in vitro (Bar-Or et al. 2001; Henn et al. 2012). In vivo, specific knockout of CD80 and CD86 on B cells alone, has been associated with decreases of both primary and secondary T-cell responses (O’Neill et al. 2007). In humans, B cells can also stimulate T cells through both CD80 and CD86 (Gimmi et al. 1991; Bar-Or et al. 2001). Genc and colleagues reported that the frequency of circulating $\mathrm{CD}^{+} 0^{+} \mathrm{B}$ cells is increased in patients with active MS (Genc et al. 1997). In addition to costimulatory molecules, B cells also express coinhibitory molecules that are involved in down-regulating the responses of effector T cells. For instance, it has been reported that B-cell PD-L1 expressed by $\mathrm{B}$ cells can protect against EAE by down-regulating T-cell responses through PD-1 (Bodhankar et al. 2013). In addition, GITRL, another coinhibitory molecule expressed by B cells, can 
directly induce Treg differentiation through glucocorticoid-induced tumor necrosis factor receptor-related (GITR) protein (Ray et al. 2012). In mice, memory B cells can be divided into two subsets, $\mathrm{PD}-\mathrm{L}^{+}{ }^{+} \mathrm{CD} 80^{+}$and PD-L2 ${ }^{-}$ $\mathrm{CD}^{-} 0^{-} \mathrm{B}$ cells, independent of their antibody isotype (Zuccarino-Catania et al. 2014). Double-positive B cells become antibody-secreting cells rapidly but cannot induce GC reaction while double-negative B cells can induce GC reaction, but very few of them can become antibody-secreting cells (Zuccarino-Catania et al. 2014). This provides an initial basis to define functionally distinct B-cell subsets, based on their different profiles of costimulatory or coinhibitory molecule expression. Whether this annotation will prove useful in humans and how different costimulatory molecule-defined B-cell subsets may contribute to MS remain to be explored.

\section{CYTOKINE-DEFINED B-CELL RESPONSES IN MS}

Cytokines are important for B cells to modulate (up- or down-regulate) local immune responses in both health and disease (Shen and Fillatreau 2015). An imbalance of B-cell pro- and antiinflammatory cytokines is now implicated in the pathophysiology of both MS and EAE (Li et al. 2015a).

\section{Interleukin-10-Producing B Cells}

Interleukin (IL)-10 is a cytokine with pleiotropic effects in inflammation and immunoregulation (Saraiva and O'Garra 2010) and IL-10-producing B cells have been extensively studied. Various stimuli can induce IL-10 production from B cells, including TLRs, CD40, microbiota, and cytokines (Lampropoulou et al. 2008; Yoshizaki et al. 2012; Rosser et al. 2014). In mice, knocking-out IL-10 selectively from B cells resulting in more severe EAE (Fillatreau et al. 2002), and adoptive transfer of in vitro-induced IL-10-producing B cells suppresses EAE in an IL-10-dependent manner (Lampropoulou et al. 2008; Matsushita et al. 2008; Yoshizaki et al. 2012). Inducing EAE in IL-10 reporter mice implicates the draining lymph nodes (rather than spleen or spinal cord) as the sites where IL- $10^{+} \mathrm{B}$ cells regulate disease-relevant immune responses (Matsumoto et al. 2014); of note, the IL- $10^{+} \mathrm{B}$ cells in this study showed plasma cell/plasmablast markers, highlighting previously unappreciated antibody-independent functions of plasma cells.

Both naïve and memory B cells can produce IL-10 in humans in a context-dependent manner (Duddy et al. 2004; Rieger and Bar-Or 2008; Blair et al. 2010; Iwata et al. 2011). Human $\mathrm{CD}^{-}$(naïve) B cells, but not CD27 ${ }^{+}$(memory) B cells, can produce IL-10 on CD40-ligand stimulation (Correale and Farez 2007; Duddy et al. 2007; Bar-Or et al. 2010; Miyazaki et al. 2014a), a response found to be abnormally deficient in MS patients' B cells (Duddy et al. 2007). Alternatively, IL- $10^{+} \mathrm{B} 10$ cells are induced within the $\mathrm{CD} 27^{+}$memory pool by stimulation through TLR4 and TLR9 and can suppress tumor necrosis factor (TNF)- $\alpha$ production by monocytes through an IL-10-dependent mechanism. B10 cells were unexpectedly reported as increased on stimulation in several human autoimmune diseases (MS included) (Iwata et al. 2011). A better understanding of these cells, which would include defining surface markers and master transcriptional regulators, would facilitate future cell-based therapies for MS.

\section{Transforming Growth Factor (TGF)- $\beta$ - Producing B Cells}

TGF- $\beta$ belongs to the TGF superfamily. So far, three isoforms of TGF- $\beta$ has been identified: TGF- $\beta 1,2,3$. As an anti-inflammatory cytokine, TGF- $\beta$ has been shown to down-regulate immune responses in various contexts ( $\mathrm{Li}$ et al. 2006). Although TGF- $\beta$-producing B cells were mainly studied in transplantation (Lee et al. 2014), relatively little is known about their role in CNS inflammation. In EAE, selective depletion of TGF- $\beta$ from B cells exacerbated EAE, in association with increased Th1 and Th17 responses (Bjarnadottir et al. 2016). Documenting functional TGF- $\beta$ production by human B cells has been difficult and their role of any in MS is not established. 


\section{IL-35-Producing B Cells}

IL-35 is an anti-inflammatory cytokine that belongs to the IL-12 family (Vignali and Kuchroo 2012) and was initially described in Tregs (Collison et al. 2007; Seyerl et al. 2010; Chaturvedi et al. 2011). Of late, IL-35-producing B cells were found to have important roles in recovery from both EAE and experimental autoimmune uveitis (Shen et al. 2014; Wang et al. 2014). In these contexts, IL-35-producing B cells inhibited proinflammatory immune responses either directly through IL-35 (Shen et al. 2014) or indirectly through induction of IL-10-producing $B$ cells (Wang et al. 2014). The same IL-35-producing B cells also showed plasma cell phenotypic markers (Shen et al. 2014). Whether human B cells/plasma cells can produce IL-35 and, if so, their potential relevance in MS, remain unclear.

\section{TNF- $\alpha$ and TNF- $\beta$ (LT- $\alpha)$-Producing B Cells}

TNF- $\alpha$ and lymphotoxin (LT)- $\alpha$ are actively involved in promoting proinflammatory immune responses to protect against pathogen invasion (Bradley 2008). TNF- $\alpha$ is known to have pathogenic roles in several autoimmune diseases including RA (Feldmann and Maini 2001) and inflammatory bowel disease (IBD) (Neurath 2014) in which TNF- $\alpha$-blocking therapies have been highly successful (Feldmann and Maini 2001). However, in MS, TNF- $\alpha$ blockade increased disease activity (Arnason 2011), which highlights the issue of largely targeting individual cytokines versus targeting particular cytokine-expressing cells. Stimulation through a combination of CD40 and the BCR significantly increases TNF- $\alpha$ and LT- $\alpha$ secretion from human B cells compared with either stimulation alone (Duddy et al. 2004). With this type of dual stimulation, the $\mathrm{B}$ cells of MS patients produce abnormally higher levels of both TNF- $\alpha$ and LT- $\alpha$ (Duddy et al. 2007; Bar-Or et al. 2010; Miyazaki et al. 2014a). In addition, TNF$\alpha$ and LT- $\alpha$ from B cells are particularly important for Th1 and Th17 responses that are implicated in MS and that decrease in patients after B-cell depletion (Bar-Or et al. 2010). Miyazaki et al. (2014a) showed that a microRNA(miR)132:SIRT1 axis modulates the expression of TNF- $\alpha$ and LT $-\alpha$ by human B cells and further showed that abnormally increased expression of miR-132 by MS B cells resulted in inhibition of the B-cell SIRT1 expression and enhanced proinflammatory cytokine production. In vitro addition of the SIRT1-agonist resveratrol normalized the exaggerated proinflammatory cytokine expression of MS B cells (Miyazaki et al. 2014a), pointing to a potential therapeutic target.

\section{IL-6-Producing B Cells}

IL-6, a cytokine that has been ascribed both proinflammatory and anti-inflammatory properties, can be produced by both immune and nonimmune cells (Kishimoto 2005). Proinflammatory effects of IL-6 include induction of Th17 cell differentiation from naïve $\mathrm{T}$ cells (Bettelli et al. 2006) and inhibition of Tregs (Korn et al. 2008; Kimura and Kishimoto 2010; Schneider et al. 2013). In contrast, IL-6 may induce IL10 -producing regulatory $\mathrm{B}$ and myeloid cells (Mauer et al. 2014; Rosser et al. 2014). B cells of MS patients are fond to secrete abnormally high levels of IL-6 (Barr et al. 2012) and IL-6 knockout selectively from $B$ cells resulted in lower Th17 responses and diminished the severity of EAE (Barr et al. 2012; Molnarfi et al. 2013). What remains unknown is how B-cell IL-6 is regulated, and whether it also contributes to Th17 differentiation and Treg-cell dysfunction in MS.

\section{IL-15-Producing B Cells}

IL-15 can be produced by multiple cell types and belongs to the four $\alpha$-helix bundle family of cytokines (Ma et al. 2006). IL-15 knockout mice develop more severe EAE (Gomez-Nicola et al. 2010), which in part is attributed to IL-15's ability to inhibit pathogenic Th17 cell differentiation (Pandiyan et al. 2012), and to induce regulatory $\mathrm{CD}^{+} \mathrm{CD}^{2} 22^{+} \mathrm{T}$ cells (Yu et al. 2014). However, in patients with MS, IL-15 in both serum and CSF is abnormally increased (Blanco-Jerez et al. 2002; Rentzos et al. 2006), where it may have the potential to promote rather than 
inhibit disease (Saikali et al. 2010; Schneider et al. 2011). MS patients' B cells reportedly produce more IL-15 than controls, and activation of B cells through CD40 and the BCR induces IL-15 secretion, enhancing both the migratory capacity of $\mathrm{CD}^{+} \mathrm{T}$ cells across a model of the blood-brain barrier, as well as $\mathrm{CD}^{+} \mathrm{T}$-cell cytotoxicity toward oligodentrocytes (Schneider et al. 2011).

\section{Granulocyte Macrophage Colony-Stimulating Factor-Producing B Cells}

During infection and autoimmune disease, granulocyte macrophage colony-stimulating factor (GM-CSF), which is an important growth factor for myeloid lineage cell development and function, is secreted by both immune and nonimmune cells (Hamilton 2008). GM-CSF knockout mice are resistant to active EAE induction (McQualter et al. 2001) and GM-CSF-deficient Th17 cells fail to induce passive EAE (Ponomarev et al. 2007; Codarri et al. 2011; El-Behi et al. 2011). Because GM-CSF-producing T cells are reportedly increased in the circulation of MS patients (Hartmann et al. 2014; Noster et al. 2014; Rasouli et al. 2015), T cells have been thought to be the main source of GM-CSF of relevance to MS and EAE (Kleinewietfeld et al. 2013; Hartmann et al. 2014; Noster et al. 2014; Rasouli et al. 2015). A murine B-cell population generated from B1 a cells, termed innate response activator (IRA) B cells (Rauch et al. 2012), was described to produce GM-CSF and found to play a GM-CSF-mediated protective role during infections (Rauch et al. 2012; Weber et al. 2014), as well as a GM-CSF-mediated pathogenic role in atherosclerosis (Hilgendorf et al. 2014). Human GM-CSF-producing B cells ( $\left.\mathrm{B}_{\mathrm{GM}-\mathrm{CSF}}\right)$ were recently described ( $\mathrm{Li}$ et al. 2015b), which, in contrast to the murine IRA cells, belong to the memory B-cell pool. Human GM-CSF-expressing $\mathrm{B}$ cells coexpress particularly high levels of TNF- $\alpha$ and IL- 6 but not IL-10 (Li et al. 2015b), and efficiently enhance myeloid cell proinflammatory responses in a GM-CSF-dependent manner. These GM-CSF-expressing B cells are abnormally increased in MS patients and antiCD20-mediated B-cell depletion results in a
B-cell-GM-CSF-dependent decrease of proinflammatory myeloid cell responses, which highlights the potential pathogenic role of this B-cell population in vivo. It also reveals a novel diseaseimplicated axis involving B cells that are myeloid cell interactions ( $\mathrm{Li}$ et al. 2015b). These proinflammatory B cells are also decreased following treatment of MS patients with either fingolimod or dimethyl fumarate (DMF) (Li et al. 2017). The recent discovery that STAT5 and STAT6 signaling reciprocally regulates human B-cell IL-10 and GM-CSF expression underscore the rationale for selective targeting of distinct B-cell populations in MS and points to novel therapeutic approaches.

\section{B CELLS AND MENINGEAL INFLAMMATION IN THE MS CNS}

There has been considerable interest in the cortical injury present in MS, and particularly the subpial cortical injury, which can be quite extensive and may represent the pathologic substrate underlying nonrelapsing progressive disease (Peterson et al. 2001; Magliozzi et al. 2007; Lucchinetti et al. 2011). In this regard, documentation of meningeal inflammation has sparked interest in the potential that immune cells fostered adjacent to the brain may contribute importantly to the subpial cortical injury (Magliozzi et al. 2010; Howell et al. 2011; Choi et al. 2012). In some cases, meningeal inflammation in MS may be organized to the extent that it recapitulates features of ectopic lymphoid structures (Magliozzi et al. 2007) as described in other contexts of chronic inflammation such as chronic infections, cancer, and autoimmune diseases (Takemura et al. 2001; Drayton et al. 2003; Pitzalis et al. 2014).

$\mathrm{B}$ cells tend to represent the predominant cell type within such immune cell collections (Magliozzi et al. 2007; Lucchinetti et al. 2011). $\mathrm{T}$ cells, follicular dendritic cells (FDCs), and stromal cell can also be found, but to a lesser extent (Magliozzi et al. 2007; Lucchinetti et al. 2011). Presence of such meningeal inflammation has been associated with earlier disease onset and more severe cortical pathology, characterized by abnormal microglia activation and 
apoptotic neuronal loss, consistent with the possibility that B-cell-rich meningeal inflammation somehow promotes propagation subpial injury and progressive MS pathology (Magliozzi et al. 2007). Emerging work has documented that soluble products of B cells isolated from MS patients can be toxic and induce apoptosis of both oligodendrocytes and neurons (Lisak et al. 2012, 2017). Tracking and targeting meningeal inflammation and particularly B cells fostered within the inflamed MS CNS has now become a new therapeutic focus in MS.

\section{CONCLUDING REMARKS}

Dysregulation of multiple immune cell subsets has been implicated in MS disease activity. Although traditionally considered a T-cell-mediated disease, important pathogenic roles of $\mathrm{B}$ cells have emerged in recent years. The contrasting results of different B-cell-targeted treatments in MS patients (despite predicted benefit from animal models) call for a better understanding of the multiple roles that distinct human B-cell subsets likely play in this illness. There remain substantial gaps in our knowledge of pathogenic and potentially regulatory B-cell responses in MS. Better understanding of their functions, how they are generated and regulated, and phenotypic markers that may reliably distinguish them from other functionally distinct subsets will eventually help develop more selective B-cell-targeting therapy in MS.

\section{REFERENCES}

Alter A, Duddy M, Hebert S, Biernacki K, Prat A, Antel JP, Yong VW, Nuttall RK, Pennington CJ, Edwards DR, et al. 2003. Determinants of human B cell migration across brain endothelial cells. J Immunol 170: 4497-4505.

Arnason B. 2011. Tumour necrosis factor neutralization in MS: A cautionary tale. Int MS J 17: 63-68.

Bagaeva LV, Rao P, Powers JM, Segal BM. 2006. CXC chemokine ligand 13 plays a role in experimental autoimmune encephalomyelitis. J Immunol 176: 7676-7685.

Barnett LG, Simkins HM, Barnett BE, Korn LL, Johnson AL, Wherry EJ, Wu GF, Laufer TM. 2014. B cell antigen presentation in the initiation of follicular helper $\mathrm{T}$ cell and germinal center differentiation. J Immunol 192: 36073617.

Bar-Or A, Oliveira EM, Anderson DE, Krieger JI, Duddy M, O'Connor KC, Hafler DA. 2001. Immunological memo- ry: Contribution of memory B cells expressing costimulatory molecules in the resting state. J Immunol 167: 5669-5677.

Bar-Or A, Calabresi PA, Arnold D, Markowitz C, Shafer S, Kasper LH, Waubant E, Gazda S, Fox RJ, Panzara M, et al. 2008. Rituximab in relapsing-remitting multiple sclerosis: A 72-week, open-label, phase I trial. Ann Neurol 63: 395400.

Bar-Or A, Fawaz L, Fan B, Darlington PJ, Rieger A, Ghorayeb C, Calabresi PA, Waubant E, Hauser SL, Zhang J, et al. 2010. Abnormal B-cell cytokine responses a trigger of T-cell-mediated disease in MS? Ann Neurol 67: 452-461.

Bar-Or A, Austin DJ, Tolson JM, VanMeter SA, Lewis E, Derosier FJ, Lopez MC, Kavanagh S, Miller AE, Sorensen PS. 2014. The MIRROR Study: A randomized, doubleblind, placebo-controlled, parallel-group, dose-ranging study to investigate the safety and MRI efficacy of subcutaneous ofatumumab in subjects with relapsing-remitting multiple sclerosis (RRMS). Neurology 82: S23.006.

Bar-Or A, Hintzen RQ, Dale RC, Rostasy K, Bruck W, Chitnis T. 2016. Immunopathophysiology of pediatric CNS inflammatory demyelinating diseases. Neurology 87: S12-S19.

Barr TA, Shen P, Brown S, Lampropoulou V, Roch T, Lawrie S, Fan B, O'Connor RA, Anderton SM, Bar-Or A, et al. 2012. B cell depletion therapy ameliorates autoimmune disease through ablation of IL-6-producing B cells. J Exp Med 209: 1001-1010.

Begum-Haque S, Sharma A, Christy M, Lentini T, OchoaReparaz J, Fayed IF, Mielcarz D, Haque A, Kasper LH. 2010. Increased expression of B cell-associated regulatory cytokines by glatiramer acetate in mice with experimental autoimmune encephalomyelitis. J Neuroimmunol 219: 47-53.

Bettelli E, Carrier Y, Gao W, Korn T, Strom TB, Oukka M, Weiner HL, Kuchroo VK. 2006. Reciprocal developmental pathways for the generation of pathogenic effector $\mathrm{T}_{\mathrm{H}} 17$ and regulatory T cells. Nature 441: 235-238.

Bjarnadottir K, Benkhoucha M, Merkler D, Weber MS, Payne NL, Bernard CC, Molnarfi N, Lalive PH. 2016. B cell-derived transforming growth factor- $\beta 1$ expression limits the induction phase of autoimmune neuroinflammation. Sci Rep 6: 34594.

Blair PA, Norena LY, Flores-Borja F, Rawlings DJ, Isenberg DA, Ehrenstein MR, Mauri C. 2010. CD $19^{+} \mathrm{CD} 24^{\text {hi }} \mathrm{CD} 38^{\mathrm{h}}$ $\mathrm{B}$ cells exhibit regulatory capacity in healthy individuals but are functionally impaired in systemic lupus erythematosus patients. Immunity 32: 129-140.

Blanco-Jerez C, Plaza JF, Masjuan J, Orensanz LM, AlvarezCermeno JC. 2002. Increased levels of IL-15 mRNA in relapsing-remitting multiple sclerosis attacks. J Neuroimmunol 128: 90-94.

Bodhankar S, Galipeau D, Vandenbark AA, Offner H. 2013. PD-1 interaction with PD-L1 but not PD-L2 on B-cells mediates protective effects of estrogen against EAE. J Clin Cell Immunol 4: 143.

Bradley JR. 2008. TNF-mediated inflammatory disease. $J$ Pathol 214: 149-160.

Brandle SM, Obermeier B, Senel M, Bruder J, Mentele R, Khademi M, Olsson T, Tumani H, Kristoferitsch W, Lottspeich F, et al. 2016. Distinct oligoclonal band antibodies 
in multiple sclerosis recognize ubiquitous self-proteins Proc Natl Acad Sci 113: 7864-7869.

Breij EC, Brink BP, Veerhuis R, van den Berg C, Vloet R, Yan R, Dijkstra CD, van der Valk P, Bo L. 2008. Homogeneity of active demyelinating lesions in established multiple sclerosis. Ann Neurol 63: 16-25.

Brickshawana A, Hinson SR, Romero MF, Lucchinetti CF Guo Y, Buttmann M, McKeon A, Pittock SJ, Chang MH, Chen AP, et al. 2014. Investigation of the KIR4.1 potassium channel as a putative antigen in patients with multiple sclerosis: A comparative study. Lancet Neurol 13: 795-806.

Brigl M, Brenner MB. 2004. CD1: Antigen presentation and T cell function. Ann Rev Immunol 22: 817-890.

Chaturvedi V, Collison LW, Guy CS, Workman CJ, Vignali DA. 2011. Cutting edge: Human regulatory T cells require IL-35 to mediate suppression and infectious tolerance. J Immunol 186: 6661-6666.

Choi SR, Howell OW, Carassiti D, Magliozzi R, Gveric D, Muraro PA, Nicholas R, Roncaroli F, Reynolds R. 2012 Meningeal inflammation plays a role in the pathology of primary progressive multiple sclerosis. Brain 135: 2925 2937.

Chung Y, Tanaka S, Chu F, Nurieva RI, Martinez GJ, Rawal S, Wang YH, Lim H, Reynolds JM, Zhou XH, et al. 2011. Follicular regulatory $\mathrm{T}$ cells expressing Foxp 3 and Bcl-6 suppress germinal center reactions. Nat Med 17: 983-988.

Codarri L, Gyulveszi G, Tosevski V, Hesske L, Fontana A, Magnenat L, Suter T, Becher B. 2011. ROR $\gamma$ t drives production of the cytokine GM-CSF in helper T cells, which is essential for the effector phase of autoimmune neuroinflammation. Nat Immunol 12: 560-567.

Coles AJ, Twyman CL, Arnold DL, Cohen JA, Confavreux C, Fox EJ, Hartung HP, Havrdova E, Selmaj KW, Weiner HL, et al. 2012. Alemtuzumab for patients with relapsing multiple sclerosis after disease-modifying therapy: A randomised controlled phase 3 trial. Lancet 380: 1829-1839.

Collison LW, Workman CJ, Kuo TT, Boyd K, Wang Y, Vignali KM, Cross R, Sehy D, Blumberg RS, Vignali DA. 2007. The inhibitory cytokine IL-35 contributes to regulatory T-cell function. Nature 450: 566-569.

Correale J, Farez M. 2007. Association between parasite infection and immune responses in multiple sclerosis. Ann Neurol 61: 97-108.

Cupps TR, Gerrard TL, Falkoff RJ, Whalen G, Fauci AS. 1985. Effects of in vitro corticosteroids on B cell activation, proliferation, and differentiation. J Clin Invest 75: 754-761.

Derfuss T, Parikh K, Velhin S, Braun M, Mathey E, Krumbholz M, Kumpfel T, Moldenhauer A, Rader C, Sonderegger P, et al. 2009. Contactin-2/TAG-1-directed autoimmunity is identified in multiple sclerosis patients and mediates gray matter pathology in animals. Proc Natl Acad Sci 106: 8302-8307.

Dhaeze T, Peelen E, Hombrouck A, Peeters L, Van Wijmeersch B, Lemkens N, Lemkens P, Somers V, Lucas S, Broux B, et al. 2015. Circulating follicular regulatory $\mathrm{T}$ cells are defective in multiple sclerosis. J Immunol 195: 832-840.

Drayton DL, Ying X, Lee J, Lesslauer W, Ruddle NH. 2003. Ectopic LT $\alpha \beta$ directs lymphoid organ neogenesis with concomitant expression of peripheral node addressin and a HEV-restricted sulfotransferase. J Exp Med 197: 11531163.

Duda PW, Schmied MC, Cook SL, Krieger JI, Hafler DA. 2000. Glatiramer acetate (copaxone) induces degenerate, Th2-polarized immune responses in patients with multiple sclerosis. J Clin Invest 105: 967-976.

Duddy ME, Alter A, Bar-Or A. 2004. Distinct profiles of human B cell effector cytokines: A role in immune regulation? J Immunol 172: 3422-3427.

Duddy M, Niino M, Adatia F, Hebert S, Freedman M, Atkins H, Kim HJ, Bar-Or A. 2007. Distinct effector cytokine profiles of memory and naïve human $B$ cell subsets and implication in multiple sclerosis. J Immunol 178: 60926099.

El-Behi M, Ciric B, Dai H, Yan Y, Cullimore M, Safavi F, Zhang GX, Dittel BN, Rostami A. 2011. The encephalitogenicity of $\mathrm{T}_{\mathrm{H}} 17$ cells is dependent on IL-1- and IL-23induced production of the cytokine GM-CSF. Nat Immunol 12: 568-575.

Feldmann M, Maini RN. 2001. Anti-TNF $\alpha$ therapy of rheumatoid arthritis: What have we learned? Ann Rev Immunol 19: 163-196.

Fillatreau S, Sweenie CH, McGeachy MJ, Gray D, Anderton SM. 2002. B cells regulate autoimmunity by provision of IL-10. Nat Immunol 3: 944-950.

Genain CP, Nguyen MH, Letvin NL, Pearl R, Davis RL, Adelman M, Lees MB, Linington C, Hauser SL. 1995. Antibody facilitation of multiple sclerosis-like lesions in a nonhuman primate. J Clin Invest 96: 2966-2974.

Genc K, Dona DL, Reder AT. 1997. Increased CD80+ B cells in active multiple sclerosis and reversal by interferon $\beta-1 \mathrm{~b}$ therapy. J Clin Invest 99: 2664-2671.

Gimmi CD, Freeman GJ, Gribben JG, Sugita K, Freedman AS, Morimoto C, Nadler LM. 1991. B-cell surface antigen $\mathrm{B} 7$ provides a costimulatory signal that induces $\mathrm{T}$ cells to proliferate and secrete interleukin 2. Proc Natl Acad Sci 88: 6575-6579.

Gomez-Nicola D, Spagnolo A, Guaza C, Nieto-Sampedro M. 2010. Aggravated experimental autoimmune encephalomyelitis in IL-15 knockout mice. Exp Neurol 222: 235 242.

Guermonprez P, Valladeau J, Zitvogel L, Thery C, Amigorena S. 2002. Antigen presentation and T cell stimulation by dendritic cells. Ann Rev Immunol 20: 621-667.

Haas J, Hug A, Viehover A, Fritzsching B, Falk CS, Filser A, Vetter T, Milkova L, Korporal M, Fritz B, et al. 2005. Reduced suppressive effect of $\mathrm{CD} 4{ }^{+} \mathrm{CD} 25^{\text {high }}$ regulatory $\mathrm{T}$ cells on the $\mathrm{T}$ cell immune response against myelin oligodendrocyte glycoprotein in patients with multiple sclerosis. Eur J Immunol 35: 3343-3352.

Hamilton JA. 2008. Colony-stimulating factors in inflammation and autoimmunity. Nat Rev Immunol 8: 533-544.

Hartmann FJ, Khademi M, Aram J, Ammann S, Kockum I, Constantinescu C, Gran B, Piehl F, Olsson T, Codarri L, et al. 2014. Multiple sclerosis-associated IL2RA polymorphism controls GM-CSF production in human $\mathrm{T}_{\mathrm{H}}$ cells. Nat Commun 5: 5056.

Hauser SL, Waubant E, Arnold DL, Vollmer T, Antel J, Fox RJ, Bar-Or A, Panzara M, Sarkar N, Agarwal S, et al. 2008. B-cell depletion with rituximab in relapsing-remitting multiple sclerosis. N Engl J Med 358: 676-688. 
Hauser SL, Bar-Or A, Comi G, Giovannoni G, Hartung HP, Hemmer B, Lublin F, Montalban X, Rammohan KW, Selmaj K, et al. 2017. Ocrelizumab versus interferon $\beta$ 1a in relapsing multiple sclerosis. N Engl J Med 376: 221234.

Henn AD, Laski M, Yang H, Welle S, Qiu X, Miao H, Barry CT, Wu H, Zand MS. 2012. Functionally distinct subpopulations of CpG-activated memory B cells. Sci Rep 2: 345 .

Henry RA, Kendall PL. 2010. CXCL13 blockade disrupts B lymphocyte organization in tertiary lymphoid structures without altering $\mathrm{B}$ cell receptor bias or preventing diabetes in nonobese diabetic mice. J Immunol 185: 14601465.

Henry RA, Kendall PL, Thomas JW. 2012. Autoantigen-specific B-cell depletion overcomes failed immune tolerance in type 1 diabetes. Diabetes 61: 2037-2044.

Hilgendorf I, Theurl I, Gerhardt LM, Robbins CS, Weber GF, Gonen A, Iwamoto Y, Degousee N, Holderried TA, Winter C, et al. 2014. Innate response activator B cells aggravate atherosclerosis by stimulating $\mathrm{T}$ helper-1 adaptive immunity. Circulation 129: 1677-1687.

Hohlfeld R, Dornmair K, Meinl E, Wekerle H. 2016a. The search for the target antigens of multiple sclerosis, part 1 Autoreactive $\mathrm{CD}^{+} \mathrm{T}$ lymphocytes as pathogenic effectors and therapeutic targets. Lancet Neurol 15: 198-209.

Hohlfeld R, Dornmair K, Meinl E, Wekerle H. 2016b. The search for the target antigens of multiple sclerosis, part 2 $\mathrm{CD}^{+} \mathrm{T}$ cells, $\mathrm{B}$ cells, and antibodies in the focus of reverse-translational research. Lancet Neurol 15: 317-331.

Howell OW, Reeves CA, Nicholas R, Carassiti D, Radotra B, Gentleman SM, Serafini B, Aloisi F, Roncaroli F, Magliozzi R, et al. 2011. Meningeal inflammation is widespread and linked to cortical pathology in multiple sclerosis. Brain 134: 2755-2771.

Hyun YM, Chung HL, McGrath JL, Waugh RE, Kim M. 2009. Activated integrin VLA-4 localizes to the lamellipodia and mediates T cell migration on VCAM-1. J Immunol 183: 359-369.

Ivers RR, Mc KB, Mc GW, Goldstein NP. 1961. Spinal-fluid $\gamma$ globulin in multiple sclerosis and other neurologic diseases. Electrophoretic patterns in 606 patients. JAMA 176: 515-519.

Iwata Y, Matsushita T, Horikawa M, Dilillo DJ, Yanaba K, Venturi GM, Szabolcs PM, Bernstein SH, Magro CM, Williams AD, et al. 2011. Characterization of a rare IL10-competent B-cell subset in humans that parallels mouse regulatory B10 cells. Blood 117: 530-541.

Kala M, Rhodes SN, Piao WH, Shi FD, Campagnolo DI, Vollmer TL. 2010. B cells from glatiramer acetate-treated mice suppress experimental autoimmune encephalomyelitis. Exp Neurol 221: 136-145.

Kappos L, Li D, Calabresi PA, O'Connor P, Bar-Or A, Barkhof F, Yin M, Leppert D, Glanzman R, Tinbergen J, et al. 2011. Ocrelizumab in relapsing-remitting multiple sclerosis: A phase 2, randomised, placebo-controlled, multicentre trial. Lancet 378: 1779-1787.

Kappos L, Hartung HP, Freedman MS, Boyko A, Radü EW, Mikol DD, Lamarine M, Hyvert Y, Freudensprung U, Plitz T, et al. 2014. Atacicept in multiple sclerosis (ATAMS): A randomised, placebo-controlled, doubleblind, phase 2 trial. Lancet Neurol 13: 353-363.
Ketelslegers IA, Van Pelt DE, Bryde S, Neuteboom RF, Catsman-Berrevoets CE, Hamann D, Hintzen RQ. 2015. AntiMOG antibodies plead against MS diagnosis in an acquired demyelinating syndromes cohort. Mult Scler 21: 1513-1520.

Kimura A, Kishimoto T. 2010. IL-6: Regulator of Treg/Th17 balance. Eur J Immunol 40: 1830-1835.

Kinnunen T, Chamberlain N, Morbach H, Cantaert T, Lynch M, Preston-Hurlburt P, Herold KC, Hafler DA, O'Connor KC, Meffre E. 2013a. Specific peripheral B cell tolerance defects in patients with multiple sclerosis. J Clin Invest 123: 2737-2741.

Kinnunen T, Chamberlain N, Morbach H, Choi J, Kim S, Craft J, Mayer L, Cancrini C, Passerini L, Bacchetta R, et al. 2013b. Accumulation of peripheral autoreactive B cells in the absence of functional human regulatory $\mathrm{T}$ cells. Blood 121: 1595-1603.

Kishimoto T. 2005. Interleukin-6: From basic science to medicine-40 years in immunology. Ann Rev Immunol 23: $1-21$.

Kleinewietfeld M, Manzel A, Titze J, Kvakan H, Yosef N, Linker RA, Muller DN, Hafler DA. 2013. Sodium chloride drives autoimmune disease by the induction of pathogenic $\mathrm{T}_{\mathrm{H}} 17$ cells. Nature 496: 518-522.

Korn T, Mitsdoerffer M, Croxford AL, Awasthi A, Dardalhon VA, Galileos G, Vollmar P, Stritesky GL, Kaplan MH, Waisman A, et al. 2008. IL-6 controls Th17 immunity in vivo by inhibiting the conversion of conventional $\mathrm{T}$ cells into Foxp $3^{+}$regulatory T cells. Proc Natl Acad Sci 105: 18460-18465.

Kostulas VK, Link H, Lefvert AK. 1987. Oligoclonal IgG bands in cerebrospinal fluid. Principles for demonstration and interpretation based on findings in 1114 neurological patients. Arch Neurol 44: 1041-1044.

Kowarik MC, Cepok S, Sellner J, Grummel V, Weber MS, Korn T, Berthele A, Hemmer B. 2012. CXCL13 is the major determinant for $\mathrm{B}$ cell recruitment to the CSF during neuroinflammation. J Neuroinflamm 9: 93.

Kraus V, Srivastava R, Kalluri SR, Seidel U, Schuelke M, Schimmel M, Rostasy K, Leiz S, Hosie S, Grummel V, et al. 2014. Potassium channel KIR4.1-specific antibodies in children with acquired demyelinating CNS disease. Neurology 82: 470-473.

Krumbholz M, Theil D, Cepok S, Hemmer B, Kivisakk P, Ransohoff RM, Hofbauer M, Farina C, Derfuss T, Hartle C, et al. 2006. Chemokines in multiple sclerosis: CXCL12 and CXCL13 up-regulation is differentially linked to CNS immune cell recruitment. Brain 129: 200-211.

Lampropoulou V, Hoehlig K, Roch T, Neves P, Calderon Gomez E, Sweenie CH, Hao Y, Freitas AA, Steinhoff U, Anderton SM, et al. 2008. TLR-activated B cells suppress T cell-mediated autoimmunity. J Immunol 180: 4763 4773.

Lee KM, Stott RT, Zhao G, SooHoo J, Xiong W, Lian MM, Fitzgerald L, Shi S, Akrawi E, Lei J, et al. 2014. TGF- $\beta$ producing regulatory $\mathrm{B}$ cells induce regulatory $\mathrm{T}$ cells and promote transplantation tolerance. Eur J Immunol 44: 1728-1736.

Lehmann-Horn K, Sagan SA, Bernard CC, Sobel RA, Zamvil SS. 2015. B-cell very late antigen- 4 deficiency reduces leukocyte recruitment and susceptibility to central nervous system autoimmunity. Ann Neurol 77: 902-908. 
Li MO, Wan YY, Sanjabi S, Robertson AK, Flavell RA. 2006 Transforming growth factor- $\beta$ regulation of immune responses. Ann Rev Immunol 24: 99-146.

Li R, Rezk A, Healy LM, Muirhead G, Prat A, Gommerman JL, Bar-Or A; MSSRF Canadian B cells in MS team. 2015a Cytokine-defined B cell responses as therapeutic targets in multiple sclerosis. Front Immunol 6: 626.

Li R, Rezk A, Miyazaki Y, Hilgenberg E, Touil H, Shen P, Moore CS, Michel L, Althekair F, Rajasekharan S, et al. 2015b. Proinflammatory GM-CSF-producing B cells in multiple sclerosis and B cell depletion therapy. Sci Transl Med 7: 310ra166.

Li R, Rezk A, Ghadiri M, Luessi F, Zipp F, Li H, Giacomini PS, Antel J, Bar-Or A. 2017. Dimethyl fumarate treatment mediates an anti-inflammatory shift in B cell subsets of patients with multiple sclerosis. J Immunol 198: 691-698.

Linterman MA, Pierson W, Lee SK, Kallies A, Kawamoto S, Rayner TF, Srivastava M, Divekar DP, Beaton L, Hogan JJ, et al. 2011. Foxp $3^{+}$follicular regulatory $\mathrm{T}$ cells control the germinal center response. Nat Med 17: 975-982.

Lisak RP, Benjamins JA, Nedelkoska L, Barger JL, Ragheb S, Fan B, Ouamara N, Johnson TA, Rajasekharan S, Bar-Or A. 2012. Secretory products of multiple sclerosis B cells are cytotoxic to oligodendroglia in vitro. J Neuroimmunol 246: 85-95.

Lisak RP, Nedelkoska L, Benjamins JA, Schalk D, Bealmear B, Touil H, Li R, Muirhead G, Bar-Or A. 2017. B cells from patients with multiple sclerosis induce cell death via apoptosis in neurons in vitro. J Neuroimmunol 309: 88-99.

Lourenco P, Shirani A, Saeedi J, Oger J, Schreiber WE, Tremlett H. 2013. Oligoclonal bands and cerebrospinal fluid markers in multiple sclerosis: Associations with disease course and progression. Mult Scler 19: 577-584.

Lovato L, Willis SN, Rodig SJ, Caron T, Almendinger SE, Howell OW, Reynolds R, O'Connor KC, Hafler DA. 2011. Related B cell clones populate the meninges and parenchyma of patients with multiple sclerosis. Brain 134: 534-541.

Lucchinetti CF, Popescu BFG, Bunyan RF, Moll NM, Roemer SF, Lassmann H, Brück W, Parisi JE, Scheithauer BW, Giannini C, et al. 2011. Inflammatory cortical demyelination in early multiple sclerosis. N Engl J Med 365: 2188-2197.

Ma A, Koka R, Burkett P. 2006. Diverse functions of IL-2, IL15, and IL-7 in lymphoid homeostasis. Ann Rev Immunol 24: 657-679.

Magliozzi R, Howell O, Vora A, Serafini B, Nicholas R, Puopolo M, Reynolds R, Aloisi F. 2007. Meningeal B-cell follicles in secondary progressive multiple sclerosis associate with early onset of disease and severe cortical pathology. Brain 130: 1089-1104.

Magliozzi R, Howell OW, Reeves C, Roncaroli F, Nicholas R, Serafini B, Aloisi F, Reynolds R. 2010. A Gradient of neuronal loss and meningeal inflammation in multiple sclerosis. Ann Neurol 68: 477-493.

Mathey EK, Derfuss T, Storch MK, Williams KR, Hales K, Woolley DR, Al-Hayani A, Davies SN, Rasband MN, Olsson T, et al. 2007. Neurofascin as a novel target for autoantibody-mediated axonal injury. J Exp Med 204: 23632372.

Matsumoto M, Baba A, Yokota T, Nishikawa H, Ohkawa Y, Kayama H, Kallies A, Nutt Stephen L, Sakaguchi S,
Takeda K, et al. 2014. Interleukin-10-producing plasmablasts exert regulatory function in autoimmune inflammation. Immunity 41: 1040-1051.

Matsushita T, Yanaba K, Bouaziz JD, Fujimoto M, Tedder TF. 2008. Regulatory B cells inhibit EAE initiation in mice while other B cells promote disease progression. J Clin Invest 118: 3420-3430.

Mauer J, Chaurasia B, Goldau J, Vogt MC, Ruud J, Nguyen KD, Theurich S, Hausen AC, Schmitz J, Bronneke HS, et al. 2014. Signaling by IL- 6 promotes alternative activation of macrophages to limit endotoxemia and obesity-associated resistance to insulin. Nat Immunol 15: 423-430.

Mayer MC, Meinl E. 2012. Glycoproteins as targets of autoantibodies in CNS inflammation: MOG and more. Ther Adv Neurol Disord 5: 147-159.

McHeyzer-Williams MG, Nossal GJ. 1988. Clonal analysis of autoantibody-producing cell precursors in the preimmune B cell repertoire. J Immunol 141: 4118-4123.

McLaughlin KA, Chitnis T, Newcombe J, Franz B, Kennedy J, McArdel S, Kuhle J, Kappos L, Rostasy K, Pohl D, et al. 2009. Age-dependent B cell autoimmunity to a myelin surface antigen in pediatric multiple sclerosis. J Immunol 183: 4067-4076.

McQualter JL, Darwiche R, Ewing C, Onuki M, Kay TW, Hamilton JA, Reid HH, Bernard CC. 2001. Granulocyte macrophage colony-stimulating factor: A new putative therapeutic target in multiple sclerosis. J Exp Med 194: 873-882.

Meffre E. 2011. The establishment of early B cell tolerance in humans: Lessons from primary immunodeficiency diseases. Ann NY Acad Sci 1246: 1-10.

Michel L, Touil H, Pikor NB, Gommerman JL, Prat A, BarOr A. 2015. B cells in the multiple sclerosis central nervous system: Trafficking and contribution to CNS-compartmentalized inflammation. Front Immunol 6: 636.

Milich DR, Chen M, Schodel F, Peterson DL, Jones JE, Hughes JL. 1997. Role of B cells in antigen presentation of the hepatitis B core. Proc Natl Acad Sci 94: 1464814653.

Miyazaki Y, Li R, Rezk A, Misirliyan H, Moore C, Farooqi N, Solis M, Goiry LG, de Faria Junior O, Dang VD, et al. 2014a. A novel microRNA-132-surtuin-1 axis underlies aberrant B-cell cytokine regulation in patients with relapsing-remitting multiple sclerosis. PLOS ONE 9: e105421.

Miyazaki Y, Niino M, Fukazawa T, Takahashi E, Nonaka T, Amino I, Tashiro J, Minami N, Fujiki N, Doi S, et al. 2014b. Suppressed pro-inflammatory properties of circulating B cells in patients with multiple sclerosis treated with fingolimod, based on altered proportions of B-cell subpopulations. Clin Immunol 151: 127-135.

Molnarfi N, Schulze-Topphoff U, Weber MS, Patarroyo JC, Prod'homme T, Varrin-Doyer M, Shetty A, Linington C, Slavin AJ, Hidalgo J, et al. 2013. MHC class II-dependent $\mathrm{B}$ cell APC function is required for induction of CNS autoimmunity independent of myelin-specific antibodies. J Exp Med 210: 2921-2937.

Nakamura M, Matsuoka T, Chihara N, Miyake S, Sato W, Araki M, Okamoto T, Lin Y, Ogawa M, Murata M, et al. 2014. Differential effects of fingolimod on B-cell populations in multiple sclerosis. Mult Scler 20: 1371-1380. 
Nerrant E, Salsac C, Charif M, Ayrignac X, Carra-Dalliere C, Castelnovo G, Goulabchand R, Tisseyre J, Raoul C, Eliaou JF, et al. 2014. Lack of confirmation of anti-inward rectifying potassium channel 4.1 antibodies as reliable markers of multiple sclerosis. Mult Scler 20: 1699-1703.

Neurath MF. 2014. Cytokines in inflammatory bowel disease. Nat Rev Immunol 14: 329-342.

Niino M, Bodner C, Simard ML, Alatab S, Gano D, Kim HJ Trigueiro M, Racicot D, Guerette C, Antel JP, et al. 2006. Natalizumab effects on immune cell responses in multiple sclerosis. Ann Neurol 59: 748-754.

Noster R, Riedel R, Mashreghi MF, Radbruch H, Harms L, Haftmann C, Chang HD, Radbruch A, Zielinski CE. 2014 IL-17 and GM-CSF expression are antagonistically regulated by human Thelper cells. Sci Transl Med 6: $241 \mathrm{ra} 280$.

O'Connor KC, Lopez-Amaya C, Gagne D, Lovato L, MooreOdom NH, Kennedy J, Krupp L, Tenembaum S, Ness J, Belman A, et al. 2010. Anti-myelin antibodies modulate clinical expression of childhood multiple sclerosis. J Neuroimmunol 223: 92-99.

O’Neill SK, Cao Y, Hamel KM, Doodes PD, Hutas G, Finnegan A. 2007. Expression of CD80/86 on B cells is essential for autoreactive $\mathrm{T}$ cell activation and the development of arthritis. J Immunol 179: 5109-5116.

Palanichamy A, Apeltsin L, Kuo TC, Sirota M, Wang S, Pitts SJ, Sundar PD, Telman D, Zhao LZ, Derstine M, et al. 2014. Immunoglobulin class-switched B cells form an active immune axis between CNS and periphery in multiple sclerosis. Sci Transl Med 6: 248ra106.

Pandiyan P, Yang XP, Saravanamuthu SS, Zheng L, Ishihara S, O'Shea JJ, Lenardo MJ. 2012. The role of IL-15 in activating STAT5 and fine-tuning IL-17A production in CD4 T lymphocytes. J Immunol 189: 4237-4246.

Peterson JW, Bo L, Mork S, Chang A, Trapp BD. 2001 Transected neurites, apoptotic neurons, and reduced inflammation in cortical multiple sclerosis lesions. Ann Neurol 50: 389-400.

Pierce SK, Morris JF, Grusby MJ, Kaumaya P, van Buskirk A, Srinivasan M, Crump B, Smolenski LA. 1988. Antigenpresenting function of B lymphocytes. Immunol Rev 106: 149-180.

Pitzalis C, Jones GW, Bombardieri M, Jones SA. 2014. Ectopic lymphoid-like structures in infection, cancer and autoimmunity. Nat Rev Immunol 14: 447-462.

Polman CH, O'Connor PW, Havrdova E, Hutchinson M, Kappos L, Miller DH, Phillips JT, Lublin FD, Giovannoni G, Wajgt A, et al. 2006. A randomized, placebo-controlled trial of natalizumab for relapsing multiple sclerosis. $N$ Engl J Med 354: 899-910.

Ponomarev ED, Shriver LP, Maresz K, Pedras-Vasconcelos J, Verthelyi D, Dittel BN. 2007. GM-CSF production by autoreactive $\mathrm{T}$ cells is required for the activation of microglial cells and the onset of experimental autoimmune encephalomyelitis. J Immunol 178: 39-48.

Probstel AK, Dornmair K, Bittner R, Sperl P, Jenne D, Magalhaes S, Villalobos A, Breithaupt C, Weissert R, Jacob U, et al. 2011. Antibodies to MOG are transient in childhood acute disseminated encephalomyelitis. Neurology 77: 580-588.

Putzki N, Baranwal MK, Tettenborn B, Limmroth V, Kreuzfelder E. 2010. Effects of natalizumab on circulating B cells, T regulatory cells and natural killer cells. Eur Neurol 63: 311-317.

Ramgolam VS, Sha Y, Marcus KL, Choudhary N, Troiani L, Chopra M, Markovic-Plese S. 2011. B cells as a therapeutic target for IFN- $\beta$ in relapsing-remitting multiple sclerosis. J Immunol 186: 4518-4526.

Ransohoff RM. 2007. Natalizumab for multiple sclerosis. $N$ Engl J Med 356: 2622-2629.

Rasouli J, Ciric B, Imitola J, Gonnella P, Hwang D, Mahajan K, Mari ER, Safavi F, Leist TP, Zhang GX, et al. 2015. Expression of GM-CSF in T cells is increased in multiple sclerosis and suppressed by IFN- $\beta$ therapy. J Immunol 194: $5085-5093$.

Rauch PJ, Chudnovskiy A, Robbins CS, Weber GF, Etzrodt M, Hilgendorf I, Tiglao E, Figueiredo JL, Iwamoto Y, Theurl I, et al. 2012. Innate response activator B cells protect against microbial sepsis. Science 335: 597-601.

Ray A, Basu S, Williams CB, Salzman NH, Dittel BN. 2012. A novel IL-10-independent regulatory role for B cells in suppressing autoimmunity by maintenance of regulatory T cells via GITR ligand. J Immunol 188: 3188-3198.

Rentzos M, Cambouri C, Rombos A, Nikolaou C, Anagnostouli M, Tsoutsou A, Dimitrakopoulos A, Triantafyllou N, Vassilopoulos D. 2006. IL-15 is elevated in serum and cerebrospinal fluid of patients with multiple sclerosis. $J$ Neurol Sci 241: 25-29.

Rieger A, Bar-Or A. 2008. B-cell-derived interleukin-10 in autoimmune disease: Regulating the regulators. Nat Rev Immunol 8: 486-487.

Rivera A, Chen CC, Ron N, Dougherty JP, Ron Y. 2001. Role of $\mathrm{B}$ cells as antigen-presenting cells in vivo revisited: Antigen-specific $\mathrm{B}$ cells are essential for $\mathrm{T}$ cell expansion in lymph nodes and for systemic $\mathrm{T}$ cell responses to low antigen concentrations. Int Immunol 13: 1583-1593.

Rodriguez-Pinto D. 2005. B cells as antigen presenting cells. Cell Immunol 238: 67-75.

Rodriguez-Pinto D, Moreno J. 2005. B cells can prime naïve $\mathrm{CD} 4^{+} \mathrm{T}$ cells in vivo in the absence of other professional antigen-presenting cells in a CD154-CD40-dependent manner. Eur J Immunol 35: 1097-1105.

Rosser EC, Oleinika K, Tonon S, Doyle R, Bosma A, Carter NA, Harris KA, Jones SA, Klein N, Mauri C. 2014. Regulatory $\mathrm{B}$ cells are induced by gut microbiota-driven interleukin-1 $\beta$ and interleukin-6 production. Nat Med 20: 1334-1339.

Sadaba MC, Tzartos J, Paino C, Garcia-Villanueva M, Alvarez-Cermeno JC, Villar LM, Esiri MM. 2012. Axonal and oligodendrocyte-localized IgM and IgG deposits in MS lesions. J Neuroimmunol 247: 86-94.

Sage PT, Alvarez D, Godec J, von Andrian UH, Sharpe AH. 2014a. Circulating T follicular regulatory and helper cells have memory-like properties. J Clin Invest 124: 51915204.

Sage PT, Paterson AM, Lovitch SB, Sharpe AH. 2014b. The coinhibitory receptor CTLA-4 controls B cell responses by modulating $\mathrm{T}$ follicular helper, $\mathrm{T}$ follicular regulatory, and T regulatory cells. Immunity 41: 1026-1039.

Saikali P, Antel JP, Pittet CL, Newcombe J, Arbour N. 2010. Contribution of astrocyte-derived IL-15 to CD8 T cell effector functions in multiple sclerosis. J Immunol 185: 5693-5703. 
Salama HH, Hong J, Zang YC, El-Mongui A, Zhang J. 2003. Blocking effects of serum reactive antibodies induced by glatiramer acetate treatment in multiple sclerosis. Brain 126: $2638-2647$.

Samuels J, Ng YS, Coupillaud C, Paget D, Meffre E. 2005. Impaired early B cell tolerance in patients with rheumatoid arthritis. J Exp Med 201: 1659-1667.

Saraiva M, O'Garra A. 2010. The regulation of IL-10 production by immune cells. Nat Rev Immunol 10: 170-181.

Sato DK, Callegaro D, Lana-Peixoto MA, Waters PJ, de Haidar Jorge FM, Takahashi T, Nakashima I, ApostolosPereira SL, Talim N, Simm RF, et al. 2014. Distinction between MOG antibody-positive and AQP4 antibodypositive NMO spectrum disorders. Neurology 82: 474481.

Schneider R, Mohebiany AN, Ifergan I, Beauseigle D, Duquette P, Prat A, Arbour N. 2011. B cell-derived IL-15 enhances CD8 T cell cytotoxicity and is increased in multiple sclerosis patients. J Immunol 187: 4119-4128.

Schneider A, Long SA, Cerosaletti K, Ni CT, Samuels P, Kita M, Buckner JH. 2013. In active relapsing-remitting multiple sclerosis, effector $\mathrm{T}$ cell resistance to adaptive Tregs involves IL-6-mediated signaling. Sci Transl Med 5: 170 ra115.

Schwarz A, Schumacher M, Pfaff D, Schumacher K, Jarius S Balint B, Wiendl H, Haas J, Wildemann B. 2013. Finetuning of regulatory $\mathrm{T}$ cell function: The role of calcium signals and naive regulatory $\mathrm{T}$ cells for regulatory $\mathrm{T}$ cell deficiency in multiple sclerosis. J Immunol 190: 49654970.

Sellebjerg F, Bornsen L, Khademi M, Krakauer M, Olsson T, Frederiksen JL, Sorensen PS. 2009. Increased cerebrospinal fluid concentrations of the chemokine CXCL13 in active MS. Neurology 73: 2003-2010.

Sergott RC, Bennett JL, Rieckmann P, Montalban X, Mikol D, Freudensprung U, Plitz T, van Beek J; ATON Trial Group. 2015. ATON: Results from a phase II randomized trial of the B-cell-targeting agent atacicept in patients with optic neuritis. J Neurol Sci 351: 174-178.

Serreze DV, Fleming SA, Chapman HD, Richard SD, Leiter EH, Tisch RM. 1998. B lymphocytes are critical antigenpresenting cells for the initiation of $\mathrm{T}$ cell-mediated autoimmune diabetes in nonobese diabetic mice. J Immunol 161: 3912-3918.

Seyerl M, Kirchberger S, Majdic O, Seipelt J, Jindra C, Schrauf C, Stockl J. 2010. Human rhinoviruses induce IL-35-producing Treg via induction of B7-H1 (CD274) and sialoadhesin (CD169) on DC. Eur J Immunol 40: 321-329.

Shen P, Fillatreau S. 2015. Antibody-independent functions of B cells: A focus on cytokines. Nat Rev Immunol 15: 441-451.

Shen P, Roch T, Lampropoulou V, O'Connor RA, Stervbo U, Hilgenberg E, Ries S, Dang VD, Jaimes Y, Daridon C, et al. 2014. IL-35-producing B cells are critical regulators of immunity during autoimmune and infectious diseases. Nature 507: 366-370.

Shlomchik MJ. 2008. Sites and stages of autoreactive B cell activation and regulation. Immunity 28: 18-28.

Sorensen PS, Lisby S, Grove R, Derosier F, Shackelford S, Havrdova E, Drulovic J, Filippi M. 2014. Safety and effi- cacy of ofatumumab in relapsing-remitting multiple sclerosis: A phase 2 study. Neurology 82: 573-581.

Srivastava R, Aslam M, Kalluri SR, Schirmer L, Buck D, Tackenberg B, Rothhammer V, Chan A, Gold R, Berthele A, et al. 2012. Potassium channel KIR4.1 as an immune target in multiple sclerosis. N Engl J Med 367: 115-123.

Stern JNH, Yaari G, Vander Heiden JA, Church G, Donahue WF, Hintzen RQ, Huttner AJ, Laman JD, Nagra RM, Nylander A, et al. 2014. B cells populating the multiple sclerosis brain mature in the draining cervical lymph nodes. Sci Transl Med 6: 248ra107.

Takemura S, Braun A, Crowson C, Kurtin PJ, Cofield RH, O'Fallon WM, Goronzy JJ, Weyand CM. 2001. Lymphoid neogenesis in rheumatoid synovitis. J Immunol 167: 1072-1080.

Takeshita Y, Ransohoff RM. 2012. Inflammatory cell trafficking across the blood-brain barrier: Chemokine regulation and in vitro models. Immunol Rev 248: 228-239.

Tintore M, Rovira A, Brieva L, Grive E, Jardi R, Borras C, Montalban X. 2001. Isolated demyelinating syndromes: Comparison of CSF oligoclonal bands and different MR imaging criteria to predict conversion to CDMS. Mult Scler 7: 359-363.

Vaeth M, Muller G, Stauss D, Dietz L, Klein-Hessling S, Serfling E, Lipp M, Berberich I, Berberich-Siebelt F. 2014. Follicular regulatory $\mathrm{T}$ cells control humoral autoimmunity via NFAT2-regulated CXCR5 expression. J Exp Med 211: 545-561.

Viglietta V, Baecher-Allan C, Weiner HL, Hafler DA. 2004. Loss of functional suppression by $\mathrm{CD} 4^{+} \mathrm{CD} 25^{+}$regulatory $\mathrm{T}$ cells in patients with multiple sclerosis. J Exp Med 199: 971-979.

Vignali DA, Kuchroo VK. 2012. IL-12 family cytokines: Immunological playmakers. Nat Immunol 13: 722-728.

Villar LM, Masjuan J, Gonzalez-Porque P, Plaza J, Sadaba MC, Roldan E, Bootello A, Alvarez-Cermeno JC. 2002. Intrathecal IgM synthesis in neurologic diseases: Relationship with disability in MS. Neurology 58: 824-826.

Villar LM, Casanova B, Ouamara N, Comabella M, Jalili F, Leppert D, de Andres C, Izquierdo G, Arroyo R, Avsar T, et al. 2014. Immunoglobulin M oligoclonal bands: Biomarker of targetable inflammation in primary progressive multiple sclerosis. Ann Neurol 76: 231-240.

von Budingen HC, Kuo TC, Sirota M, van Belle CJ, Apeltsin L, Glanville J, Cree BA, Gourraud PA, Schwartzburg A, Huerta G, et al. 2012. B cell exchange across the bloodbrain barrier in multiple sclerosis. J Clin Invest 122: 45334543.

Walters SN, Webster KE, Daley S, Grey ST. 2014. A role for intrathymic B cells in the generation of natural regulatory T cells. J Immunol 193: 170-176.

Wang RX, Yu CR, Dambuza IM, Mahdi RM, Dolinska MB, Sergeev YV, Wingfield PT, Kim SH, Egwuagu CE. 2014 Interleukin-35 induces regulatory B cells that suppress autoimmune disease. Nat Med 20: 633-641.

Wardemann H, Yurasov S, Schaefer A, Young JW, Meffre E, Nussenzweig MC. 2003. Predominant autoantibody production by early human B cell precursors. Science 301: 1374-1377.

Waters PJ, McKeon A, Leite MI, Rajasekharan S, Lennon VA, Villalobos A, Palace J, Mandrekar JN, Vincent A, 
Bar-Or A, et al. 2012. Serologic diagnosis of NMO: A multicenter comparison of aquaporin-4-IgG assays. Neurology 78: 665-671; discussion 669.

Weber MS, Prod'homme T, Patarroyo JC, Molnarfi N, Karnezis T, Lehmann-Horn K, Danilenko DM, EasthamAnderson J, Slavin AJ, Linington C, et al. 2010. B-cell activation influences T-cell polarization and outcome of anti-CD20 B-cell depletion in central nervous system autoimmunity. Ann Neurol 68: 369-383.

Weber MS, Hemmer B, Cepok S. 2011. The role of antibodies in multiple sclerosis. Biochim Biophys Acta 1812: 239-245.

Weber GF, Chousterman BG, Hilgendorf I, Robbins CS, Theurl I, Gerhardt LM, Iwamoto Y, Quach TD, Ali M, Chen JW, et al. 2014. Pleural innate response activator B cells protect against pneumonia via a GM-CSF-IgM axis. J Exp Med 211: 1243-1256.

Wing JB, Ise W, Kurosaki T, Sakaguchi S. 2014. Regulatory T cells control antigen-specific expansion of Tfh cell number and humoral immune responses via the coreceptor CTLA-4. Immunity 41: 1013-1025.

Winger RC, Zamvil SS. 2016. Antibodies in multiple sclerosis oligoclonal bands target debris. Proc Natl Acad Sci 113: 7696-7698.

Yoshizaki A, Miyagaki T, DiLillo DJ, Matsushita T, Horikawa M, Kountikov EI, Spolski R, Poe JC, Leonard WJ,
Tedder TF. 2012. Regulatory B cells control T-cell autoimmunity through IL-21-dependent cognate interactions. Nature 491: 264-268.

Yu P, Bamford RN, Waldmann TA. 2014. IL-15-dependent $\mathrm{CD} 8^{+} \mathrm{CD} 122^{+} \mathrm{T}$ cells ameliorate experimental autoimmune encephalomyelitis by modulating IL-17 production by $\mathrm{CD}^{+}{ }^{+} \mathrm{T}$ cells. Eur J Immunol 44: 3330-3341.

Yurasov S, Wardemann H, Hammersen J, Tsuiji M, Meffre E, Pascual V, Nussenzweig MC. 2005. Defective B cell tolerance checkpoints in systemic lupus erythematosus. J Exp Med 201: 703-711.

Zeng Q, Ng YH, Singh T, Jiang K, Sheriff KA, Ippolito R, Zahalka S, Li Q, Randhawa P, Hoffman RA, et al. 2014. B cells mediate chronic allograft rejection independently of antibody production. J Clin Invest 124: 1052-1056.

Zhou D, Srivastava R, Nessler S, Grummel V, Sommer N, Bruck W, Hartung HP, Stadelmann C, Hemmer B. 2006. Identification of a pathogenic antibody response to native myelin oligodendrocyte glycoprotein in multiple sclerosis. Proc Natl Acad Sci 103: 19057-19062.

Zuccarino-Catania GV, Sadanand S, Weisel FJ, Tomayko MM, Meng H, Kleinstein SH, Good-Jacobson KL, Shlomchik MJ. 2014. CD80 and PD-L2 define functionally distinct memory B cell subsets that are independent of antibody isotype. Nat Immunol 15: 631-637. 


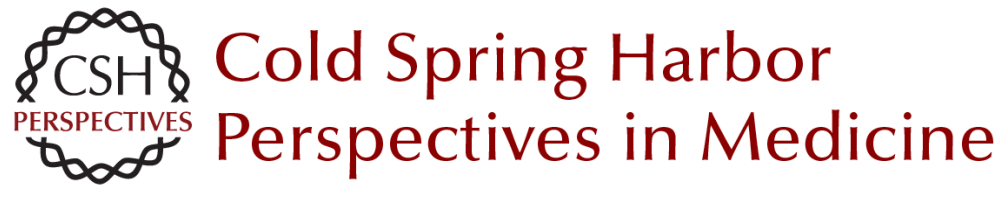

\section{The Multiple Roles of B Cells in Multiple Sclerosis and Their Implications in Multiple Sclerosis Therapies}

Rui Li and Amit Bar-Or

Cold Spring Harb Perspect Med 2019; doi: 10.1101/cshperspect.a029108 originally published online April 16, 2018

\begin{tabular}{|c|c|}
\hline Jbject Collection Multiple Sclerosis & \\
\hline $\begin{array}{l}\text { Multiple Sclerosis Pathology } \\
\text { Hans Lassmann }\end{array}$ & $\begin{array}{l}\text { Natalizumab: Perspectives from the Bench to } \\
\text { Bedside } \\
\text { Afsaneh Shirani and Olaf Stüve }\end{array}$ \\
\hline $\begin{array}{l}\text { Regulatory T Cells: From Discovery to } \\
\text { Autoimmunity } \\
\text { Alexandra Kitz, Emily Singer and David Hafler }\end{array}$ & $\begin{array}{l}\text { Daclizumab Therapy for Multiple Sclerosis } \\
\text { Bibiana Bielekova }\end{array}$ \\
\hline $\begin{array}{l}\text { The Multiple Roles of B Cells in Multiple Sclerosis } \\
\text { and Their Implications in Multiple Sclerosis } \\
\text { Therapies } \\
\text { Rui Li and Amit Bar-Or }\end{array}$ & $\begin{array}{l}\text { Lifestyle and Environmental Factors in Multiple } \\
\text { Sclerosis } \\
\text { Lars Alfredsson and Tomas Olsson }\end{array}$ \\
\hline $\begin{array}{l}\text { Autologous Hematopoietic Stem Cell } \\
\text { Transplantation in the Treatment of Multiple } \\
\text { Sclerosis } \\
\text { Carolina A. Rush, Harold L. Atkins and Mark S. } \\
\text { Freedman }\end{array}$ & $\begin{array}{l}\text { Biomarkers in Multiple Sclerosis } \\
\text { Anu Paul, Manuel Comabella and Roopali Gandhi }\end{array}$ \\
\hline $\begin{array}{l}\text { B-Cell Therapies in Multiple Sclerosis } \\
\text { Joseph J. Sabatino, Jr., Scott S. Zamvil and } \\
\text { Stephen L. Hauser }\end{array}$ & $\begin{array}{l}\text { The Evolving Mechanisms of Action of Glatiramer } \\
\text { Acetate } \\
\text { Thomas Prod'homme and Scott S. Zamvil }\end{array}$ \\
\hline $\begin{array}{l}\text { Oral Therapies for Multiple Sclerosis } \\
\text { Simon Faissner and Ralf Gold }\end{array}$ & $\begin{array}{l}\text { Regulation of Astrocyte Functions in Multiple } \\
\text { Sclerosis } \\
\text { Michael A. Wheeler and Francisco J. Quintana }\end{array}$ \\
\hline $\begin{array}{l}\text { Interferon } \beta \text { for Multiple Sclerosis } \\
\text { Dejan Jakimovski, Channa Kolb, Murali } \\
\text { Ramanathan, et al. }\end{array}$ & $\begin{array}{l}\text { Experimental Autoimmune Encephalomyelitis } \\
\text { (EAE) as Animal Models of Multiple Sclerosis (MS) } \\
\text { Simon Glatigny and Estelle Bettelli }\end{array}$ \\
\hline $\begin{array}{l}\text { Alemtuzumab as Treatment for Multiple Sclerosis } \\
\text { Serafeim Katsavos and Alasdair Coles }\end{array}$ & $\begin{array}{l}\text { Neurodegeneration in Progressive Multiple } \\
\text { Sclerosis } \\
\text { Graham Campbell and Don Mahad }\end{array}$ \\
\hline
\end{tabular}

For additional articles in this collection, see http://perspectivesinmedicine.cshlp.org/cgi/collection/ 